Crime, Histoire \& Sociétés / Crime, History \& Societies

Vol. 5, n`2 | 2001

Varia

\title{
New Standards for Historical Homicide Research
}

\section{Eric Monkkonen}

\section{OpenEdition}

Journals

Electronic version

URL: https://journals.openedition.org/chs/733

DOI: $10.4000 /$ chs.733

ISSN: 1663-4837

\section{Publisher}

Librairie Droz

\section{Printed version}

Date of publication: 1 January 2001

Number of pages: 5-26

ISBN: 2-600-00664-8

ISSN: 1422-0857

\section{Electronic reference}

Eric Monkkonen, "New Standards for Historical Homicide Research", Crime, Histoire \& Sociétés / Crime, History \& Societies [Online], Vol. 5, n² | 2001, Online since 02 April 2009, connection on 22 March 2022. URL: http://journals.openedition.org/chs/733 ; DOI: https://doi.org/10.4000/chs.733 


\title{
New Standards for Historical Homicide Research
}

\author{
Eric Monkkonen
}

Les historiens de la violence disposent dorénavant de douzaines, voire de centaines, de taux d'homicides de bonne qualité pour la plus grande partie de l'hémisphère occidental. Nous nous trouvons donc dans une situation qui, conformément à l'usage, implique d'entreprendre synthèse et généralisation. Un effort de ce type est méritoire et doit être poursuivi, mais il est temps de revenir à une recherche empirique beaucoup plus soigneuse, et les avancées significatives réalisées jusqu'ici devraient nous inciter à rehausser encore la qualité de nos recherches. Pour le dire simplement: si des recherches plus sophistiquées confirmaient les travaux antérieurs, ce serait positif. Si inversement, elles modifiaient nos résultats, nous devrions leur faire bonne figure et repenser nos grandes questions et nos analyses en conséquence.

Historians of violence now have dozens, even hundreds, of high quality homicide rates for much of the Western world. We are now in a position which would, by custom, demand the beginning of synthesis and generalization. Such efforts are of merit and should continue, but it is time that we turn back to much more careful empirical research. Our substantive gains should give us the confidence to raise even higher the quality of our research. Simply put, if refined research efforts confirm previous work, this is comforting. On the other hand, if they change or modify findings, we should welcome the new results and rethink our big questions and analyses.

$\mathrm{T}$ he study of personal violence has come a long way in the years since Ted Gurr and Alfred Soman wrote their path breaking essays synthesizing large bodies of scholarly work; the best internal critique of the oeuvre thus far has been articulated by Spierenburg ${ }^{2}$. There are now hundreds of studies (over 300 according

1 Eric Monkkkonen is Professor at the University of California (Los Angeles). He is the author of five books on American cities, police, and crime. His most recent book is Murder in New York City (University of California Press, 2001), a study covering two centuries of homicides. Following his exhortations in this article, his research in progress is a reconstruction of age standardized homicide rates in the turn of the century (1900) United States. He holds joint appointments in the Departments of History and Policy Studies at the University of California, Los Angeles (UCLA). An earlier version of the paper was presented at the European Social Science History meeting, Amsterdam, April 2000. He is indebted to the panelists - Pieter Spierenburg, Manuel Eisner, Helmut Thome - and to the audience for comments which helped me sharpen some of the points. He wishes to give special thanks to David Eisenmann, M.D., and Susan Lambe, M.D. for their help in understanding the time to death data. The research in this paper was supported by grants from the National Science Foundation, the National Consortium on Violence Research, and the UCLA Academic Senate.

2 Soman (1980); Gurr (1981, 1989); Spierenburg (1996). 
to Eisner), rather than the dozen or so on which Gurr and Soman based their essays. ${ }^{3}$ Because of these studies, we now know that we can get a firm grasp on personal violence well into the past. There are now several fruitful theoretical ways to examine violence, from the civilizing process to classical Durkheimian sociology to evolutionary psychology ${ }^{4}$. There is a growing international standard of definition and communication which makes cross national comparisons ordinary, rather than merely wished for: researchers now make explicit their definitions of what they include as homicide and regularly per capitize their results.

This paper deals briefly with the empirical problems of this long term synthesis, and then focuses on what I believe should be new international research standards. The subject of violence is restricted here to mortal personal violence, homicide, and does not address other forms of violence which do not result in death. It makes no claims that homicide indexes other kinds of violence, but rather assumes that homicide, in and of itself, is a significant enough aspect of violence to merit singular attention. The argument is simple: the time has come for new levels of quality in data gathering. Just as the beginnings of cross national and theoretically interesting analysis came from the discoveries made by high quality empirical research, the next step is to refine the data and then to refine the questions.

I.

In their syntheses, both Gurr and Soman juxtaposed disparate studies - studies characterized by focused, non comparative research efforts - to show a now familiar picture reproduced in Figure 1: the decline from very high rates of personal violence in the middle ages to relatively low rates by the late nineteenth century, at least in Europe. It is important to remember how startling these results were as they refuted scholarly wisdom and theory, the romantic notion of a peaceful communal past overcome by the violence of urban industrial order. This change in understanding, while now thorough in the community which studies crime, has probably still not penetrated conventional wisdom, even though a highly visible article on the synthesis appeared in Past \& Present 5 .

Since the 1980s, continuing research on levels of personal violence appears to buttress the Gurr/Soman synthesis. Most recently Ylikangas has summarized a large number of studies of Nordic countries, adding many new places to the list ${ }^{6}$. A summary graph of these new studies still resembles the Gurr graph, with the virtue of many new data points. Ylikangas' thorough review of these studies suggests that the long turn decline is a robust empirical finding, and he argues that the Elias thesis applies across many more places than just the core European nations.

Should we conclude that the empirical question is now settled? That «violent past, peaceful present» describes our world? Should we move on to other questions? I believe not, for several reasons.

3 Eisner (2001).

4 Spierenburg (1996), Thome (2001); Daly, Wilson (1988).

5 Stone (1983); see also Sharpe $(1981,1982)$.

6 Ylikangas (2000). 


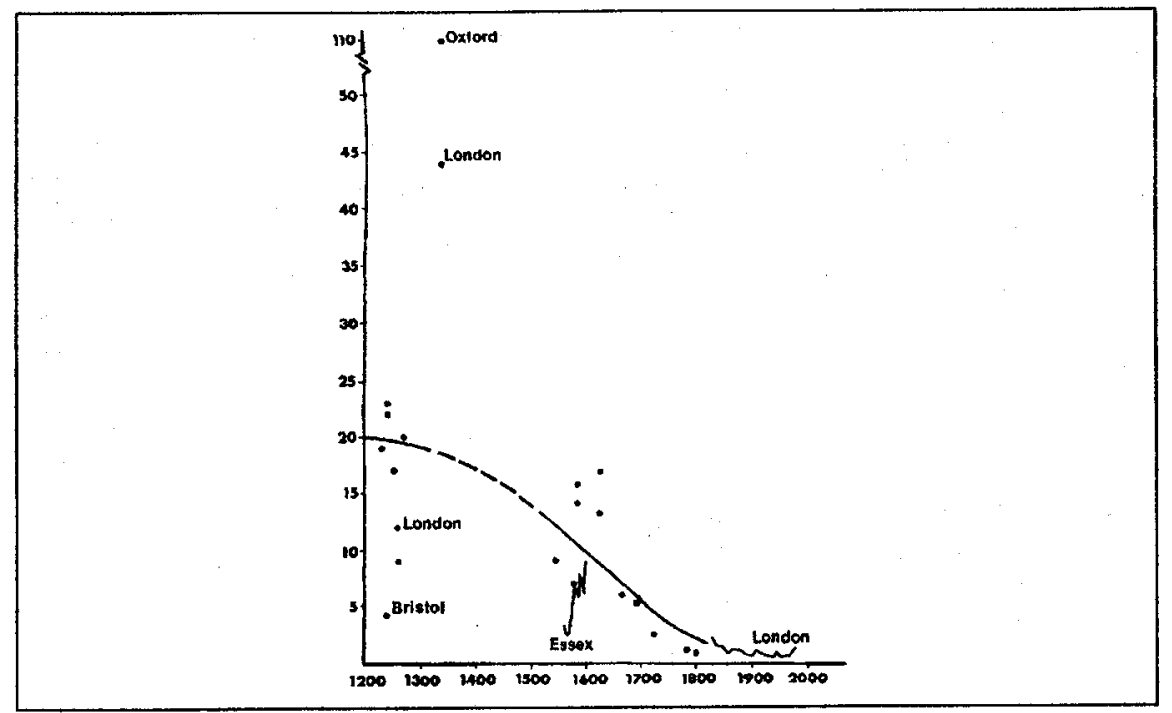

Figure 1: Gurr's original graph. Source: Gurr (1981).

\section{Spolty Knowledge}

First, consider the awkward problem of those places that we actually know about. Given the lack of knowledge about medieval and early modern populations, we do not really know how representative the study sites have been. We do not even know what proportion of a region's population has been studied. In an era when few people lived in cities, it may be necessary to study large rural areas or sets of villages.

The cliche that it easy to lie with statistics needs a corollary: it is even easier to lie without statistics. Limited information is much better than none, but we should not stop with our current limits. The more studies we get, the better: a large sample will give us some confidence that the generalizations we have been accepting are reasonable. Since we may never have a good sense of the populations of the medieval and much of the early modern world, we may have to substitute many study sites with unknown biases for fewer and more representative study sites. The notion of adding piece by piece to knowledge truly applies to this research: it is a thousand piece puzzle, or series of puzzles, to which many projects contribute.

Nevertheless, no matter how well done the individual studies, the data are very hard to interpret and we must confront this issue. The individual studies give us homicide rates for places which may vary enormously in size, and we do not know if a few small places distort the picture. If we suspect that a few small or large places do distort the overall picture, we may need to consider them separately, arguing, as it were, over tiny pieces in the larger puzzle. Consider the impact of the homicide count in Hammer's pioneering and justly well regarded study of Oxford ${ }^{7}$. Because the city was so small (approximately 6000 ), two unusual years with high violence

7 Hammer (1978). 
could have easily produced the high rates. Two riots, say, with ten dead each, would be enough to account for the rates he found (this would yield 166 per hundred thousand per year). If the city returned to a normal high rate of one death per year, the rate would then be 16 per hundred thousand: high but not the bizarre extreme Hammer discovered. It is odd that such a pioneering and important article has not generated follow up studies - say, the next decades or century in Oxford or a parallel study of another university town.

Note that many other important cities, for example Bergen in 1600 , had populations as small as Oxford's. In the case of small study sites one must be more careful because the numerator of homicide counts can exert high power when converted to rates per hundred thousand. If, for instance, a city of 6000 reported a death a year because the coroner or his equivalent met in that city but viewed the evidence from deaths in the surrounding region, one would have an apparent homicide rate of 16 per hundred thousand. Similarly, if there was a feud in a city of 6000 , and for three years there was a single homicide a year, but then none for the subsequent twenty years, the rate should not be reported as 16,7 per hundred thousand for three years, but smoothed to 2,2 per hundred thousand ( 3 divided by 138000 (that is, 6000 times 23 years) then multiplied by 100000 ). Or, if a city's reported population excluded the non-resident sojourners, their size would have to be estimated. With small denominators, seemingly trivial differences can be converted into dramatic rate differences. Extreme caution is in order.

A similar critique may not apply to medieval London - its size precluding distortions caused by numerator error or size - but note that if for some unknown reason its rates have been overestimated, then the shape of the line in Figure 1, the basis for Gurr's original analysis, is not nearly so dramatic.

To highlight the extraordinary potential for misunderstanding caused by the inadvertent selection of atypical study sites, consider the United States in 1996, about which we have very good data (see the Appendix). I use here FBI murder statistics on just those 188 cities with populations greater than 100000 . Even for these current data, it is important to note that some cities are not listed by this source due to reporting failures; we do not know what difference this might have made. Two of the highest murder rate cities were also among the smallest in size. San Antonio had the highest murder rate, 55,2, and a population of only 107000 , while third highest was Gary, Indiana (rate 35,1), with a population of 111000 . If we were delving into American violence from afar and had selected these two cities, both in the middle of the country, one in the north and one in the south, we would think violence very high, especially among smaller cities (if we knew enough to know that these were in fact smaller cities). We almost might think that the north and the south had similar homicide rates. Or, if we had compared 1996 Gary to 2000 San Antonio, we would think something else, for in the intervening 4 years San Antonio's rate had plummeted $^{8}$.

On the other hand, twelve of these 188 largest US cities had no murders, none. The chances are one in sixteen that a scholar could have selected one of these cities for a homicide study. If, for example, one had selected Plano, Texas, population of 192000 and no murders, one might have concluded wrongly that Texas was violence free.

8 See http://www.ci.sat.tx.us/sapd/UCR.htm. 
Further, an unweighted average of these three example cities - Gary, San Antonio, and Plano - would give a very poor understanding of the whole, 30 homicides per hundred thousand. The actual mean rate for all 188 cities was 8,8 . The extremes pull up this mean, for only 43 of these 188 cities actually had murder rates at the average or higher. Fully half of the United States cities had rates of 4,4 or less. So, there is a fifty percent probability that one would select a study city with a homicide rate half that of the national urban mean. The major lesson to take away is that a sample of cities can produce huge biases and that without full information, these cannot be known easily if at all. We have the ability to standardize to a population base of 100000 , to make the comparisons accurate, but the places may be highly different.

One apparent solution to the problem of cross site comparison has been to look at trends in one place: again, the actual place may not capture the whole. In the United States, the much discussed decline in homicide rates from 1991 to the present occurred in 100 of these largest 188 cities, but homicide rates increased in 81.

Given this potentially devastating critique, and the remote likelihood that we will ever recreate past statistics with the coverage of those of the late twentieth century, should we give up? Of course not: but we should try to compensate, to examine with care each new case, and to ask scholars to produce some estimates of what they would guess that their sample means. For example, contextual information might suggest that a place had a reputation for being violent or quiet; we could then asterisk such cases when plotting them. Or, we could weight reported city rates by a crude Big, Medium, or Small size category, based on a scholar's assessment of the study city's size relative to other cities in that region and era. Then, when producing composite graphs like Gurr's, the plotted symbols of the largest cities could be made larger than those of the smallest ones. In this approach, little Oxford at 6 000 persons would be a tiny speck when contrasted with London at 80000 . This would give the plot much more analytic power. We might also add to each new set of study sites a date of completion so that when plotted, one could see if newer studies support or contradict older ones as they get added in.

\section{II.}

The power of violence research, especially homicide research, is that deaths are usually reported, and that we can come to some core agreements about what we can count as a homicide. For example, infanticide and the murder of very young children has been treated so inconsistently and the cause of death so often poorly reported that most scholars exclude infanticide and the murder of young children from their counts: consistency, not ethical judgement, determines this choice'. One consequence is a slight undercount in violence rates - in the late twentieth century United States, for example, victims under five years old account for two to three percent of all murders.

Just as there is some agreement on what can be counted as a homicide, the contemporary practice of reporting deaths as a rate - per annum counts per hundred

9 For a critique of this practice, see Emmerichs (2000) and Nadel (2000). 
thousand population base - is highly standardized. These two basic practices which derive from the growth of international vital statistics - have fostered the international and across time comparisons ${ }^{10}$.

\section{Missing Homicides}

However, even with agreement or definitional clarity as to what gets counted as a homicide, an obvious problem with the violent event count is the question of what has been missed. The possible missing events stem from three causes:

One, damaged or misplaced records;

Two, incomplete recording - from hidden homicides to sloppy record keeping; and

Three, systematic biases - for example, a recording practice which mentions only crimes with known assailants (typically, trial based records).

There is a very good and well established way of testing for observations omitted or unrecorded in the counts, known as «capture-recapture» or the Chandra-SekarDeming method. The technique is used by animal researchers to count things like the number of fish in a lake and by demographers for estimating populations in places without regular censuses ${ }^{11}$. The requirements for the technique lend themselves to historical homicide research : one needs two separate lists of unique identifiers, e.g., one list of victims from the coroner and another from a newspaper, or, perhaps, one list of offenders from jail registries and another from indictments. Given two lists, one can use capture-recapture sampling to estimate the number of events missed, that is the homicides mentioned in neither. The technique assumes that each sample or list is an independent random sample: this is most certainly not the case with historical homicide lists. The bias introduced by what are probably correlated, non independent lists, is a conservative one: thus the estimates of missed homicides is low. As most researchers prefer to err on the side of conservatism, this is an important side note, a consequence of working with historical documents as opposed to fish. An important paper by Douglas Eckberg on nineteenth century South Carolina homicides clearly explains the technique, which I follow here ${ }^{12}$.

Table One shows the results of several different re-estimates for two cities, New York and Los Angeles. These examples are based on my own recent archival work ${ }^{13}$. Note in the Table that for some years in the nineteenth century, my original New York estimates were relatively far off the mark, but that in general, the proportion of homicides missed was less than ten percent. This gives good confirmation that my original estimates were not wildly off. But on three occasions, the technique provides a powerful corrective: New York 1860 and 1863, and Los Angeles for 1909. Of these three, the New York correctives were already available in other sources, which had reported annual homicide counts. But, for Los Angeles, 1909, several months of coroner inquests's were missing, and without this sampling method, the year would have had to be omitted from any subsequent analysis. Thus, the technique can not only provide a strong corrective to known source problems, but it can also corroborate the original data.

10 See United States (1995) for the American part of the story of vital statistics.

11 Chenuil, Crespin, Pouyaud, Patrick, (2000); Sydeman, Nur, McLaren, McChesney, (1998).

12 Eckberg (1998); Monkkonen (2001b).

13 Monkkonen (2001b). 
Table 1: Homicide counts \& capture-recapture estimates (New York City)

\begin{tabular}{|l|c|c|}
\hline Year & Original count* & Capture-recapture estimate \\
\hline $1784-1820$ & 109 & 129 \\
\hline 1853 & 57 & 59 \\
\hline 1854 & 46 & 47 \\
\hline 1855 & 39 & 41 \\
\hline 1856 & 41 & 43 \\
\hline 1857 & 94 & 106 \\
\hline 1858 & 59 & 60 \\
\hline 1860 & 68 & 108 \\
\hline 1861 & 47 & 63 \\
\hline 1862 & 46 & 53 \\
\hline 1863 & 59 & 89 \\
\hline $1865^{* *}$ & 67 & 75.2 \\
\hline 1867 & 55 & 66.25 \\
\hline
\end{tabular}

* In the original New York City research (Monkkonen, 2001a) the strategy had been to use the highest number of homicides, whether the number came from individual murders compiled from coroners's reports, newspaper and other sources or it came from an annual count mentioned in a public health or other published reports. For the capture-recapture analysis, with the exception of the first cell, a new list of individual names was gathered from newspaper sources alone and this list was then used against the list of names from the coroner's inquests. For the first cell, the comparison list was from a record ui prison admissions (see Monkkonen, $2001 \mathrm{~b}$, for further details). In the second panel of this table, for Los Angeles, the sources were simpler: coroner's reports and newspaper articles.

** $\mathrm{N} 1$ (Times index only) $=12-\mathrm{N} 2$ (Coroner's inquests only) $=21-\mathrm{C}$ (in both) $=35-$ Estimation total $=\mathrm{N} 1+\mathrm{N} 2+\mathrm{C}+(\mathrm{N} 1 * \mathrm{~N} 2) / \mathrm{C}-$ For $1865=12+21+35+7.2=75.2$

Table 1: (continued) Los Angeles City and County

\begin{tabular}{|l|c|c|}
\hline Year & Coroner inquest count & Capture-recapture estimate \\
\hline 1899 & 11 & 12 \\
\hline 1900 & 10 & 12.4 \\
\hline 1901 & 16 & 21.7 \\
\hline 1909 & 18 (missing pages) & 42 \\
\hline 1911 & 44 & 46.4 \\
\hline 1919 & 59 & 62.5 \\
\hline
\end{tabular}

Recently, Howard Taylor has published a powerful argument that, under fiscal pressure to save money, nineteenth century English coroners deliberately under- 
counted homicides $^{14}$. Rather than a dispute over what might or might not have happened, capture-recapture would provide a simple test of Taylor's thesis. Readily available newspapers and coroners records would provide the two lists required. Of course, a scholarly dispute without further evidence may prove more interesting, even if providing little new information.

\section{Denominator problems}

A problem parallel to the missed homicides in the numerator also exists in the denominator, the population estimates. It seems to be an historical law that places with good victim lists have poor base population counts. Most historians are grateful to have even crude population estimates with which to per capitize their hard earned murders. Few would consider actually making better population counts as this would be an entirely different - and time consuming - research project. Yet, it is conceivable to deal with the problem of poor quality population counts with the same sampling method as for the violent event counts: demographers use capture recapture sampling principally to estimate populations in countries without censuses, after all. One thinks for example, of the extraordinary high homicide rates that Hammer found for Oxford. This city cries out for more research: we may all accept the homicide counts, but why should we believe the population estimates? Hammer carefully discusses and evaluates the various sources for his estimate: but we should note that this small population of 6000 could well have been estimated on its permanent, rather than temporary population.

\section{Population age structure}

Should one get to the point of carefully estimated missingness for the numerator and denominator, there is a third and equally vexing challenge: the age and sex structure of the population at risk. We would expect to have few violent events in a society composed of women over sixty years old. Yet for the most part we happily create violence measures which assume that the population denominator is unproblematic, that the same population proportions by age and gender are parallel across vast reaches of history and geography. Murders per 100000 as a measure is such an advance over previous knowledge and such an achievement in itself, that we seldom ask what kind of population base we have employed.

Surely, a new mining town filled with men between the ages of 20 and 40 is not the same as a retirement village where the average age is 60 . Would we per capitize murder rates (if any) for these two sites without some careful thinking? More to the point, for long term historical studies, is the substantially more youthful population of nineteenth century and early modern places: was the age structure of the middle ages a fundamental cause of high violence rates? Does not our standard usage of population denominators mask something equally as basic? Do we need to ask more questions about the population of fourteenth century Oxford? Was it composed primarily of men exactly in the years most at risk for violence? If so, the extraordinary rates should be reduced to $20 \%$ or $30 \%$ of those reported, placing them at a still high but not wild level of 25 per hundred thousand and leaving London as the highest point on Gurr's graph.

14 Taylor (1998a, 1998b). 
Consider two example cities: Turin in 1705 and New York in 1850. The mean age for men in both cities is similar, 24 in New York and 27 in Turin. (The sex balance for both is similar : $49 \%$ men in Turin, $50,5 \%$ in New York.) This information alone does not tell us much. However, the actual age distribution tells us a great deal. Figure 2 plots the distribution by age of males in these two cities. We see that New York has a bulge of men in the age group 18 to 35, just the age at which we expect to see more criminal violence. One can only guess at what a plot for fourteenth century London or Oxford would look like.

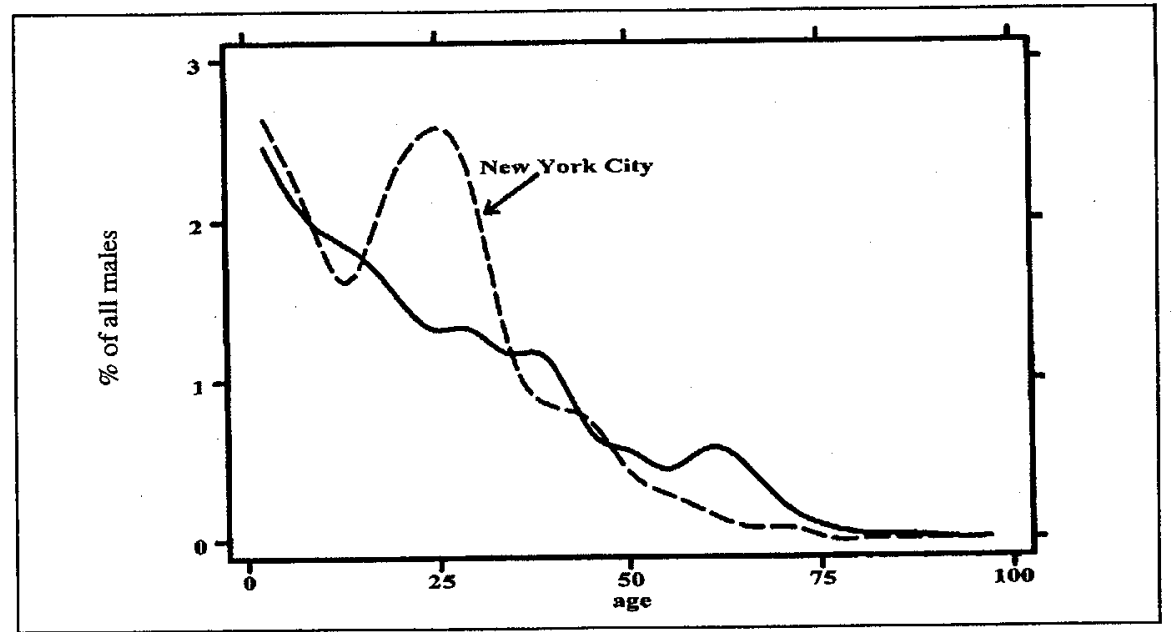

Figure 2: Male age distributions, New York (1850) and Turin (1705).

Source: Symcox and Monkkonen (1994).

Fortunately, there is a well established method for correcting for dissimilar population numerators, known as age standardizing. The research reported on here represents an initial set of age standardized homicide rates. It serves as a cautionary tale, and I hope also demonstrates the costs and benefits of even more careful research standards. Age standardization is relatively simple computationally, requiring a systematic attention to detail which should conform well with normal historical research practices. To do the analysis, one must have the age distribution of the original population and of the homicide victims or offenders. Clearly, the age of the offenders is the more important measure, but typically the age of the victim is much more thoroughly reported ${ }^{15}$. The ages of victims and offenders are usually only loosely correlated, but the distributions are close to one another. (In the 1700 individual pre 1875 New York City homicides analyzed in Monkkonen (2001a), the mean age of 379 offenders was 30,1 years and of 783 victims over five was 31,8 . The correlation of the two, for men alone, was $r=36$.) Standard age categories are less than 1 year old, 1-4, 5-14, 15-24, 25-34, 35-44, 55-64, 65-64, 75 and up $^{16}$. In the

15 See Monkkonen (1999) for a discussion of nineteenth century offender age data.

16 See Anderson and Rosenberg for a discussion of the new standards (1998, p. 13). 
analysis which follows, I have not corrected for sex, only age, in part because sex balance was similar for all of my comparison cities. All rate distributions are recalculated to make the comparison population the whole United States in 2000: note that the actual base population is arbitrary - only consistency is required ${ }^{17}$.

Table Two displays the adjustments in per capita homicide rates for six different cities. It should be noted at the outset that most of these cities, with the exception of 1830 New York, have good quality census population data and that the homicide counts come from an era beginning to emphasize the systematic collection of vital statistics. Arguably, the cities share important characteristics affecting violence : all were undergoing rapid immigration and population growth, all had booming economies and great inequality ${ }^{18}$. One would not have expected dramatic differences for the cities shown here. Yet for three, the age standardized differences are substantial, with the most dramatic change for 1830 New York, an $85 \%$ increase. All of the other cities show a decrease in the rates when age standardized, the decrease ranging from a modest $5 \%$ to a large $32 \%$.

These new calculations reverse the rank order for the first two cities, New York and Liverpool ${ }^{19}$. The rates for Los Angeles remain the highest in the group: when the Los Angeles rate is inflated to account for the $25 \%$ found missing by capturerecapture, the city had the very high rate of 19 per hundred thousand.

Table 2: Original and age standardized homicide rates : rank ordered.

\begin{tabular}{|c|c|c|c|}
\hline Homicides & per & 100,000 & \\
\hline Place (date) & ctual ( 3 yr average) & Age standardized & Percent change \\
\hline NYC* 1830 & 2.6 & 4.8 & $85 \%$ \\
\hline Liverpool* 1861 & 5.7 & 3.9 & $-32 \%$ \\
\hline San Francisco* 1880 & 7.45 & 7.1 & $-5 \%$ \\
\hline Chicago 1910 & 10.5 & 7.6 & $-28 \%$ \\
\hline St. Louis 1900 & 12.6 & 10.2 & $-19 \%$ \\
\hline LA City* 1900 & 16.6 & 15.3 & $-8 \%$ \\
\hline
\end{tabular}

* Los Angeles based on homicides 1895-1904; Liverpool based on 1852-1865; New York City based on 1825-1834; San Francisco based on two fiscal years, 1879-1880, 1880-1881. Note that San Francisco may have excluded Chinese. Source: see text.

Figures 3 and 4 plot New York City homicide rates over a nearly two century span to illustrate the effects of that city's changing age structure. Figure 3 shows the period 1820 to 1960 in order to examine the era of low homicide rates, while Figure 4 shows the whole long span. The broken line is for the age standardized rates: the solid line shows the conventional rates per hundred thousand.

17 The actual re-estimates are done in Stata using the direct age standardization program (StataCorp, 1999).

18 See Gallman (2000) for an excellent summary of Liverpool's social situation.

19 Note that these examples have not been verified using capture recapture. 


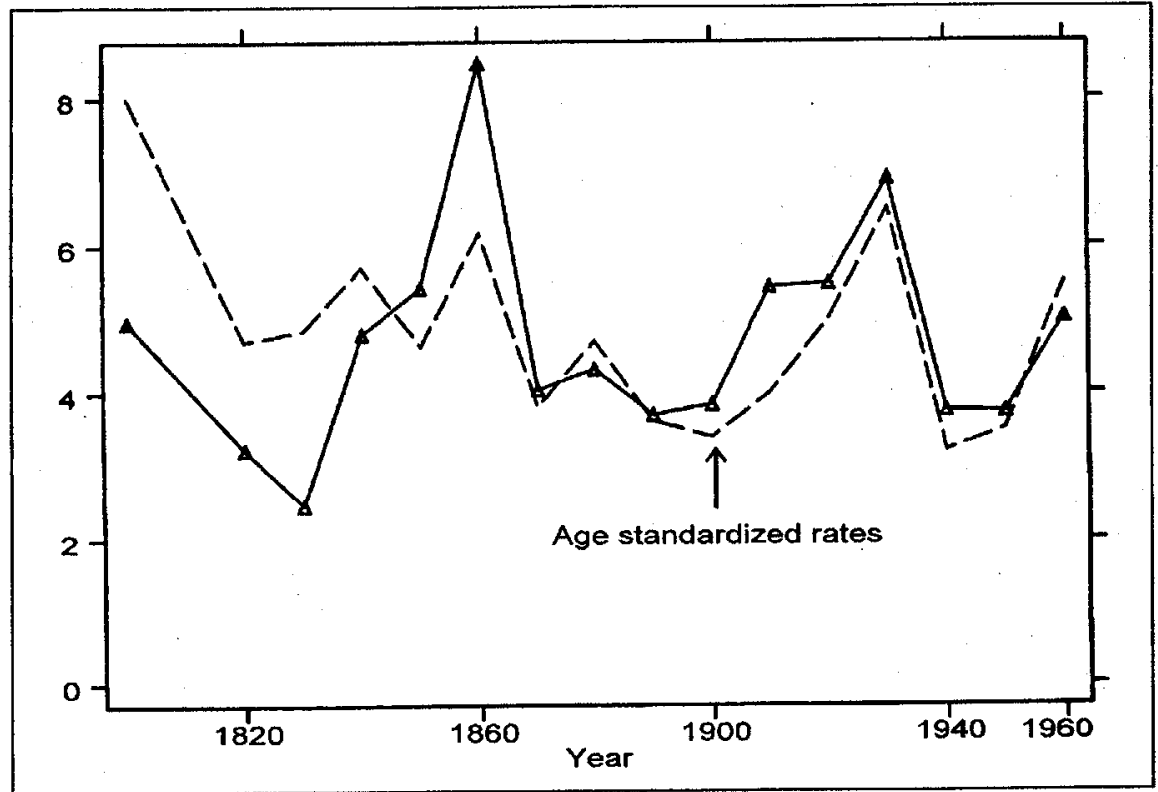

Figure 3: New York City homicides per 100,000 (solid line) and age standardized rates (broken line), 1820-1960. Source: see text.

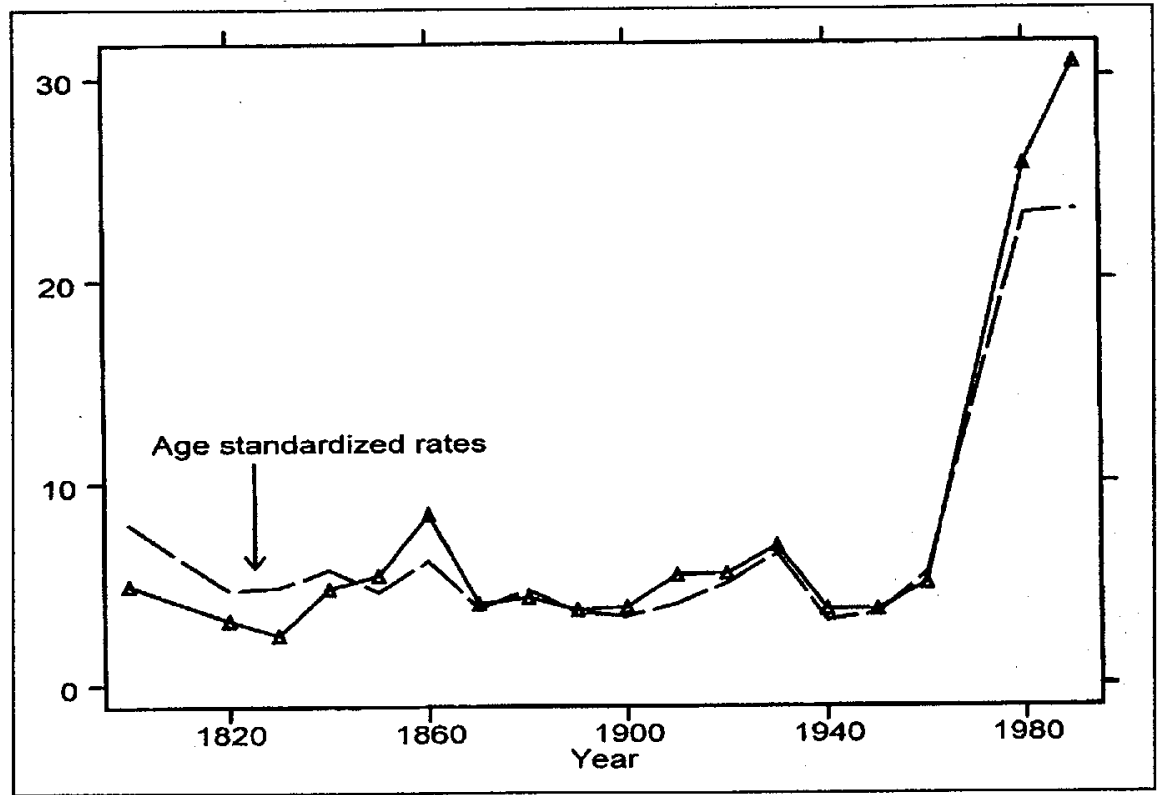

Figure 4: New York City homicides per 100,000 (solid line) and age standardized rates (broken line), 1820-1990. Source: see text. 
In both figures it is clear that age has made a difference even in this single city, sometimes dampening violence peaks and at others inflating them. All of the sharpest peak years - 1860,1930,1980, and 1990 - are moderated by age standardization. The lowest year, 1830 , is raised. These corrections are only on the decade, so one presumes that other peaks and valleys would be similarly modified were age distributions available on an annual basis. The violent mid nineteenth and late twentieth centuries are still violent, but the contrasts are moderated. The effect is as though a string had been drawn through the plot and pulled tight, smoothing the peaks and filling the valleys. Although visually moderate, several inter- decadal trends are changed, even reversed. For instance, the period 1820 to 1830 saw an increase, not a decrease, 1910-1920 saw an increasing instead of stable trend, and 1940-1950 saw an increase, not stability.

An additional limitation to age standardization is that when one is estimating population, often the age distribution is unavailable. In both Table 2 and Figures 3 and 4, the data are reported on the decade because this is when the census enumeration occurred. Interpolating on an annual basis might be satisfactory for the cruder counts per hundred thousand denominator, but will not be satisfactory with age grouping. Accounting for immigration is simply too difficult. So, the gain in decadal quality is offset by the loss in the interesting annual fluctuations. For the pre 1880 years, I have used a ten year span of victims' ages, centered on the decade: this avoids the distortion problem caused by small numbers. The best research strategy may therefore be to establish the best counts possible and do spot estimations of both missing data and the age standardized rate. This will not be the same as the best possible set of corrected annual rates, but it will be a good sign of whether or not age and missing events have skewed the analysis.

\section{Changing medical practice, belter weapons}

Violence scholars often puzzle over the question, «What would have happened with today's medical care ?» Looking at long term violence rates, this is the question raised by almost all non historians about the data. Few have tried to deal systematically with this, and the usual solution is to hope that today's improved medical care is offset equally by improved weapons ${ }^{20}$. Should we think so? Not answering this question implies that it is impossible to assess. Certainly we may never have - either for today or the distant past - exactly the information we need: this would include both fatal as well as non fatal assaults, the type of injury and the progress of the injuries either to death or to recovery, and the kind and effect of the medical interventions. However, we often can get information on the injuries leading to death, in particular the kind of weapon, and on the elapsed time from injury to death. This basic information offers the possibility of many insights.

For the twentieth century, both the time from injury to medical care and the changes in medical care itself have reduced mortality from injury. For American combat injuries in World War I, the modal time from injury to treatment was 12-18 hours, with a mortality rate of $8,5 \%$ : the time dropped to $6-12$ hours in World War II, and mortality dropped to 5,8\%. During the Korean conflict, often cited as an era

20 Lane (1979, pp. 78-80) may have been the first historian to bring this question explicitly in view. See also Spierenburg (1996 at note 78 ). 
of major advances in trauma care, treatment occurred between 2 and 4 hours, with a dramatically improved mortality rate of $2,4 \%^{21}$.

Figure 5 shows the estimated time from assault to death for a hundred and fifty mid nineteenth century New York City homicide victims ${ }^{22}$. The hours expressed are maximums: that is, someone dying instantly I coded as one hour, whereas an ambiguously noted time might be a maximum of twenty four hours and possible as low as twelve. Missing cases simply had hopelessly ambiguous notations - «died yesterday» or «died shortly thereafter» - or were reconstructed from a sketchily reported criminal trial with no information about the conflict itself.

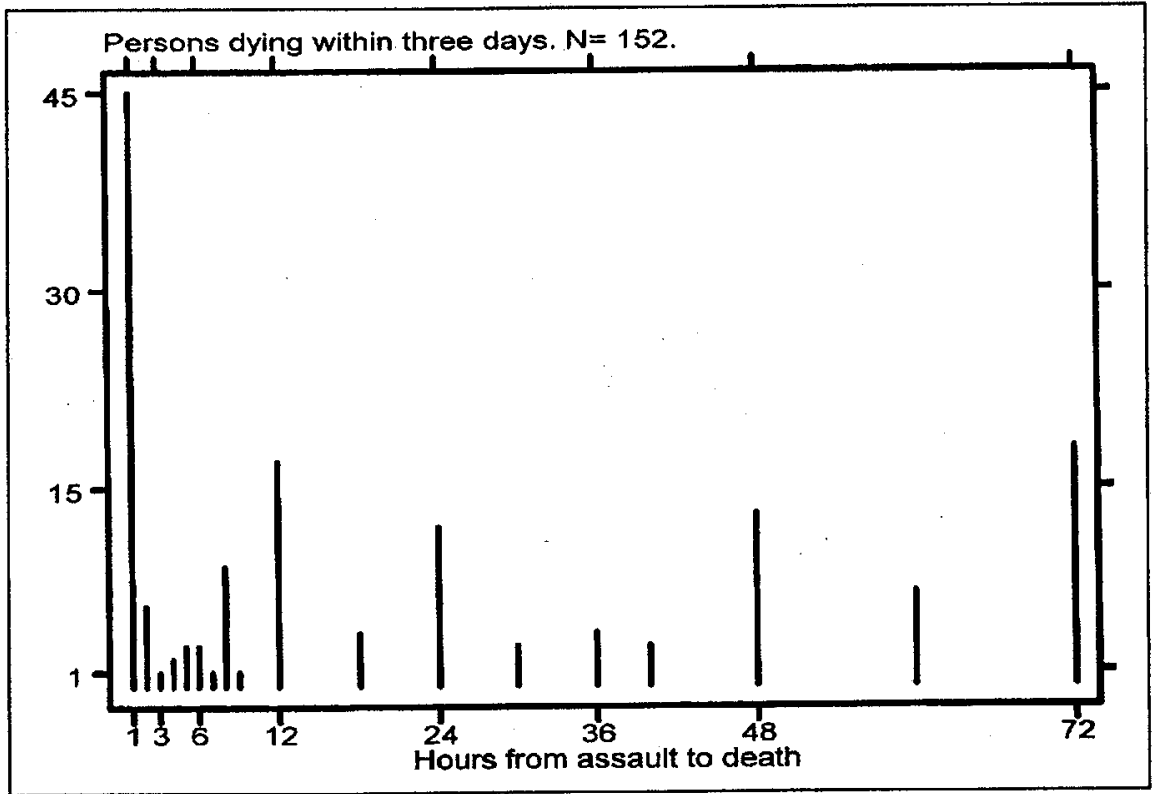

Figure 5: Time from assault to death for those dying within three days (72\% of all victims), nineteenth century New York City. Source: Monkkonen (2000a).

These data allow the big question, «How would contemporary medical intervention have affected murder rates?» to be addressed, if with huge qualifications. One can see in the picture the onset of infections, and the consequences of blood loss which occurred in three or so days after the assault. Doctors familiar with violent assaults think that many of the post twenty four hour deaths could have been prevented with today's medicine, whereas the deaths occurring in less than one hour (often called the «Golden Hour») were probably not preventible. The third group, deaths one to six hours after assault, those now treated in trauma rooms, have a pos-

21 American College of Surgeons (1990, p. 9).

22 For the years $1857,1859-1861$ there were 277 homicide victims, for 214 of whom I was able to get a good time to death estimate. 
sible $50 \%$ save rate $e^{23}$. By this standard, about fifty percent of the mid nineteenth century New York City homicide deaths would have been preventable had the assaults occurred in a modern city (all $24 \%$ of those who died in two hours or less; $2 \%$, half of the group who died in 3-6 hours; plus $24 \%$, one third of the group who died after 6 hours).

What about the second half of the then versus now question: improved modern weapons? Figure 6 separates the time to death by major weapons. In the figure, «other» weapons include everything from drowning and defenestration to mainly blows with feet, hands, and sticks.

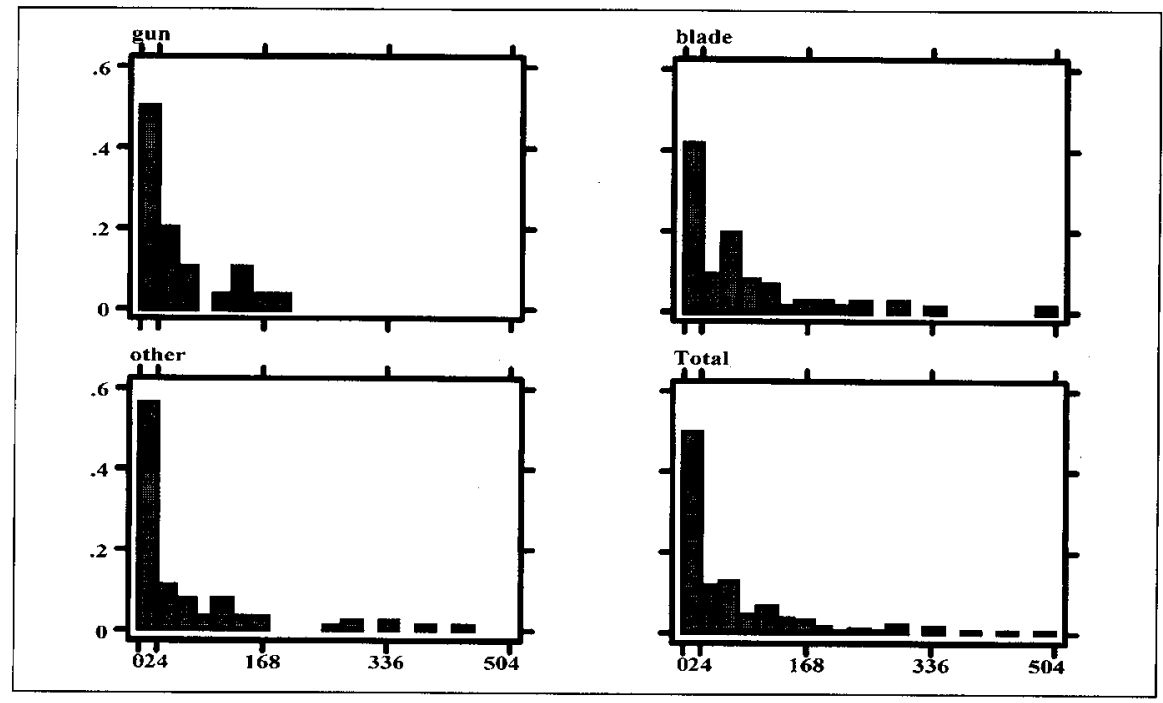

Figure 6: Time to death by weapon, New York City, nineteenth century. The median time is 24 hours for guns, 48 for bladed weapons and 18 for other weapons. (Cases with time to death ranging for three weeks to four months have been dropped for visual clarity.) $\mathrm{N}=32$ for guns, 78 for blade, 101 other and 211 for total. Source. see text.

The differences by weapon are instructive. For guns, the initial burst of deaths probably came from bleeding, with the second group - after two days from injury from infection ${ }^{24}$.

Bladed weapons must have caused a large proportion (50\%) of deaths due to internal bleeding and infection: inquests occasionally mention peritonitis. Half of all knife deaths came after two days, while half of all gun deaths came within a day.

The « other » category has a slightly quicker time to death: the initial large group of deaths probably coming from brain injury and internal hemorrhaging, with secondary infections accounting for the long trailing out of post injury deaths shown in the lower left panel of Figure 6. Does this initial burst of quick death reflect the

23 Drs. Eisenmann and Lambe, assisted my analysis of these data.

24 Wilson, Walt (1996, p. 859). 
greater determination of the assailant? The scenario of stab wounds was often that the victim fled or offender departed after one or two thrusts, while fights involving blows, sticks and rocks sometimes continued until one person died.

Today, handguns account for about $75 \%$ of all murders in New York City, so if we triple the weapon proportion of nineteenth century murders and save the lives of all those surviving at least 24 hours, there would be approximately a $50 \%$ reduction in deaths. On the other hand, in a world where all involved in violent confrontations were accustomed to a leisurely conclusion to bloody conflict, who is to say that assailants might not have turned to surer forms of assault - sticks and stones, say ? That is, if violent men (93\% of all offenders in this sample were men) knew that medical intervention could thwart their attacks, might they have followed through more decisively, more often?

In the $21^{\text {st }}$ century, we imagine murder to be sudden and decisive. Not so in the nineteenth century. In a large number of murders, after inflicting an injury, the offender was taken to jail «to await the results of the injuries.» Or, many news stories titled «Fatal Affray» concluded, often erroneously, that the victim «surely will die.» These phrases, so very common, suggest that in the pre electronic age, nothing happened that fast, whether a shipwreck or a homicidal confrontation. Ante mortem depositions were very common: part of a fatal confrontation was the time afterwards, when all - medical personnel, friends and relatives of victim and offender, the coroners and juries, police, and offender - just waited. The well known 1869 murder of Albert Richardson, a prominent journalist, by Daniel McFarland, is instructive ${ }^{25}$. McFarland had previously attempted to shoot Richardson but had failed. The second time he fired from a distance of three feet, in public, in the outer office of Richardson's newspaper. Richardson then lingered in a room at the best hotel - the Astor House - for almost two weeks, while various treatments - «injections» of milk, beef tea, brandy and a «fine spray of rum» on the face (for fever) were administered. Though the whole story of the stalking and assaults reeks of McFarland's ineptitude and delay, he succeeded. One presumes that had there been swifter and surer medical attention, McFarland would have compensated with a swifter and surer attack. So, if we imagine that modern medicine would have saved poor Richardson, we would also have to imagine a different attack as well. A third attack, perhaps, or a more vicious first one.

None of the examples fully developed in this paper show a shocking reassessment in violence rates. None suggest that the proposed refinements will erase the familiar picture of high medieval homicides. This may be in part because all of the examples are from the nineteenth and twentieth centuries. If in the future scholars do similar readjustments and test missing information and come up with similar robustness for medieval and early modern rates, that is all to the good. But, until we have used these higher standards, we must be cautious in the long run and wide ranging comparisons which have become an important part of the field of violence studies. It is probable that capture-recapture will yield more homicides but that the age adjusting will lower the rates. But, this should not be a topic for guessing. In addition, the very small size of many study sites should come in for special scrutiny: a more predictable pattern will be of great unevenness over time and space, while introducing the years and places with no homicides will lower the reported rates 
considerably. We may discover that medieval and early modern rates were more in the range 5 to 15 per hundred thousand.

A finding of more erratic and unpredictable rates of personal violence, rather than consistently high rates, actually fits current theory quite well. Whether from the point of view of Durkheim or Elias, a slow rise in predictable and stable human interactions, in city and country, is exactly what we should find. This leaves the decline in violence hypothesis moderated yet still intact and built on a sounder basis. The hypothesis is far too important to stand untested and unrefined, as it now does.

Eric Monkkonen School of Public Policy and Social Research (UCLA)

Department of Policy Studies

6265 Bunche Hall 405 Hilgard Avenue Los Angeles, California 90024-1473 USA

Emonkkon@ucla.edu

\section{Appendix: Homicide rates in U.S. cities $>100000$ population, 1996}

\begin{tabular}{lccc} 
City & State & $\begin{array}{c}\text { Homicides } \\
/ 100 \mathrm{k}\end{array}$ & $\begin{array}{c}\text { Population } \\
\text { in 100k }\end{array}$ \\
\hline SimiValley & CA & 0 & 107 \\
Boise & ID & 0 & 153 \\
Clearwater & FL & 0 & 100 \\
Irvine & CA & 0 & 128 \\
Orange & CA & 0 & 120 \\
Plano & TX & 0 & 192 \\
Madison & WI & 0 & 198 \\
Naperville & I & 0 & 107 \\
Huntington Beach & CA & 0 & 191 \\
Ann Arbor & MI & 0 & 109 \\
Springfield & MA & 0 & 150 \\
Sunnyvale & CA & 0 & 125 \\
Fremont & CA & 5 & 188 \\
Garden Grove & CA & 7 & 149 \\
Santa Clarita & CA & 8 & 125 \\
Santa Rosa & CA & 8 & 122 \\
Sterling Heights & MI & 8 & 119 \\
Independence & MO & 9 & 110 \\
Grand Prairie & TX & 9 & 109 \\
Livonia & MI & 1 & 105 \\
Lincoln & NE & 1 & 209 \\
Fort Collins & CO & 1 & 104 \\
Allentown & PA & 1 & 102 \\
West Covina & CA & 1 & 102 \\
Anaheim & CA & 1 & 289
\end{tabular}




\begin{tabular}{|c|c|c|c|}
\hline City & State & $\begin{array}{l}\text { Homicides } \\
/ 100 \mathrm{k}\end{array}$ & $\begin{array}{l}\text { Population } \\
\text { in } 100 \mathrm{k}\end{array}$ \\
\hline El Paso & $\mathrm{TX}$ & 1.2 & 600 \\
\hline Tempe & $\mathrm{AZ}$ & 1.2 & 163 \\
\hline Chula Vista & $\overline{\mathrm{CA}}$ & 1.3 & 152 \\
\hline Oceanside & $\mathrm{CA}$ & 1.4 & 146 \\
\hline Springfield & MO & 1.4 & 143 \\
\hline Torrance & $\mathrm{CA}$ & 1.5 & 136 \\
\hline Riverside & $\mathrm{CA}$ & 1.6 & 255 \\
\hline Eugene & OR & 1.6 & 124 \\
\hline Henderson & NV & 1.6 & 122 \\
\hline Thousand Oaks & $\mathrm{CA}$ & 1.8 & 113 \\
\hline Mesquite & $\mathrm{TX}$ & 1.8 & 112 \\
\hline El Monte & $\mathrm{CA}$ & 1.8 & 110 \\
\hline Virginia Beach & VA & 1.9 & 430 \\
\hline Palmdale & $\mathrm{CA}$ & 1.9 & 107 \\
\hline Seattle & WA & 1.9 & 525 \\
\hline Berkeley & $\mathrm{CA}$ & 1.9 & 103 \\
\hline Green Bay & WI & 2 & 102 \\
\hline Tallahassee & FL & 2.2 & 137 \\
\hline San Jose & $\mathrm{CA}$ & 2.3 & 839 \\
\hline Amarillo & $\mathrm{TX}$ & 2.4 & 170 \\
\hline Worcester & $\mathrm{MA}$ & 2.4 & 166 \\
\hline Laredo & $\mathrm{TX}$ & 2.4 & 165 \\
\hline Evansville & IN & 2.4 & 123 \\
\hline Fullerton & $\mathrm{CA}$ & 2.5 & 120 \\
\hline Alexandria & $\mathrm{VA}$ & 2.6 & 118 \\
\hline Reno & NV & 2.6 & 155 \\
\hline Grand Rapids & MI & 2.7 & 188 \\
\hline Springfield & II & 2.7 & 113 \\
\hline Salinas & $\mathrm{CA}$ & 2.7 & 112 \\
\hline Stamford & $\mathrm{CT}$ & 2.7 & 110 \\
\hline Abilene & $\mathrm{TX}$ & 2.8 & 108 \\
\hline Irving & $\mathrm{TX}$ & 2.8 & 177 \\
\hline Erie & PA & 2.8 & 105 \\
\hline Corpus Christi & $\mathrm{TX}$ & 2.9 & 280 \\
\hline Hampton & VA & 2.9 & 139 \\
\hline Mesa & $\mathrm{AZ}$ & 2.9 & 345 \\
\hline Lexington & KY & 2.9 & 240 \\
\hline Norwalk & $\mathrm{CA}$ & 3 & 100 \\
\hline Wichita Falls & $\mathrm{TX}$ & 3 & 100 \\
\hline Honolulu CDP & $\mathrm{HI}$ & 3.1 & 423 \\
\hline Chesapeake & VA & 3.1 & 192 \\
\hline Hayward & $\mathrm{CA}$ & 3.3 & 122 \\
\hline Omaha & $\mathrm{NE}$ & 3.3 & 364 \\
\hline Austin & $\mathrm{TX}$ & 3.3 & 541 \\
\hline Modesto & $\mathrm{CA}$ & 3.4 & 179 \\
\hline San Diego & $\mathrm{CA}$ & 3.4 & 1171 \\
\hline
\end{tabular}


City

State Homicides Population $/ 100 \mathrm{k}$ in $100 \mathrm{k}$

Rancho Cucamonga

Escondido

3.4

117

Concord

CA

3.4

116

Huntsville

$\mathrm{CA}$

3.5

115

Peoria

Anchorage

Lubbock

AL

3.5

170

IL

3.6

112

AK

3.6

251

Savannah

Yonkers

TX

3.6

194

GA

3.7

136

Arlington

NY

3.7

190

Glendale

TX

3.7

Glendale

$\mathrm{CA}$

3.8

295

$\mathrm{AZ}$

Syracuse

Paterson

New Haven

NY

NJ

Orlando

CT

3.8

184

Wichita

FL

Salem

Garland

KS

3.8

182

Moreno Valley

OR

4

156

150

4

125

Spokane

TX

4

174

Columbus

CA

4.1

320

4.1

123

4.2

190

WA

4.3

141

GA

4.3

187

Toledo

Tacoma

$\mathrm{OH}$

4.4

183

Tulsa

WA

4.4

318

OK

4.5

179

4.5

378

Brownsville

TX

4.5

132

Pasadena

TX

4.6

132

Providence

St. Petersburg

RI

Waterbury

FL

4.6

153

CT

4.7

236

Lansing

Albany

Hialeah

Greensboro

MI

4.7

106

NY

4.8

126

FL

4.8

104

$\mathrm{NC}$

Lancaster

$\mathrm{CA}$

4.9

205

Macon

GA

5.1

195

5.2

116

Fort Worth

TX

5.3

113

Elizabeth

NJ

Ontario

Waco

CA

5.4

480

5.4

110

TX

5.5

NJ

5.5

145

Jersey

Lafayette

Tampa

LA

5.7

108

FL

5.7

229

TN

6

105

Chattanooga

PA

Pittsburgh

Portland

OR

6

285

150

350

$\begin{array}{ll}6 & 351\end{array}$




\begin{tabular}{|c|c|c|c|}
\hline City & State & $\begin{array}{l}\text { Homicides } \\
/ 100 \mathrm{k}\end{array}$ & $\begin{array}{l}\text { Population } \\
\text { in } 100 \mathrm{k}\end{array}$ \\
\hline San Francisco & $\mathrm{CA}$ & 6.1 & 735 \\
\hline Bakersfield & $\mathrm{CA}$ & 6.3 & 206 \\
\hline Oklahoma & $\mathrm{OK}$ & 6.4 & 470 \\
\hline Denver & $\mathrm{CO}$ & 6.4 & 498 \\
\hline Boston & MA & 6.4 & 558 \\
\hline Oxnard & $\mathrm{CA}$ & 6.6 & 151 \\
\hline Sacramento & $\mathrm{CA}$ & 6.6 & 376 \\
\hline Topeka & $\mathrm{KS}$ & 6.7 & 120 \\
\hline Fontana & $\mathrm{CA}$ & 6.7 & 104 \\
\hline Newport News & VA & 6.8 & 176 \\
\hline New York & NY & 6.9 & 7381 \\
\hline Raleigh & $\mathrm{NC}$ & 7 & 244 \\
\hline Hollywood & FL & 7 & 128 \\
\hline Jacksonville & FL & 7.1 & 680 \\
\hline Knoxville & TN & 7.2 & 168 \\
\hline Vallejo & $\mathrm{CA}$ & 7.3 & 110 \\
\hline Indianapolis & IN & 7.4 & 747 \\
\hline Pasadena & $\mathrm{CA}$ & 7.5 & 134 \\
\hline Houston & $\mathrm{TX}$ & 7.7 & 1744 \\
\hline Columbus & $\mathrm{OH}$ & 7.8 & 657 \\
\hline Phoenix & $\mathrm{AZ}$ & 7.9 & 1159 \\
\hline Columbia & $\mathrm{SC}$ & 8 & 113 \\
\hline Buffalo & $\mathrm{NY}$ & 8.1 & 311 \\
\hline Hartford & CT & 8.3 & 133 \\
\hline Santa Ana & $\mathrm{CA}$ & 8.3 & 302 \\
\hline Nashville & $\mathrm{TN}$ & 8.4 & 511 \\
\hline Fresno & $\mathrm{CA}$ & 8.6 & 396 \\
\hline Cleveland & $\mathrm{OH}$ & 8.6 & 498 \\
\hline Charlotte & $\mathrm{NC}$ & 8.8 & 441 \\
\hline Pomona & $\mathrm{CA}$ & 8.9 & 135 \\
\hline Albuquerque & $\mathrm{NM}$ & 9.3 & 420 \\
\hline Louisville & $\mathrm{KY}$ & 9.6 & 261 \\
\hline Stockton & $\mathrm{CA}$ & 9.9 & 233 \\
\hline Beaumont & TX & 9.9 & 111 \\
\hline Little Rock & $\mathrm{AR}$ & 10.2 & 176 \\
\hline Milwaukee & WI & 10.3 & 591 \\
\hline Rochester & NY & 10.4 & 222 \\
\hline Los Angeles & $\mathrm{CA}$ & 10.4 & 3554 \\
\hline Norfolk & VA & 10.7 & 233 \\
\hline Dallas & TX & 10.8 & 1053 \\
\hline San Bernardino & $\mathrm{CA}$ & 11.4 & 183 \\
\hline Winston-Salem & $\mathrm{NC}$ & 11.7 & 154 \\
\hline Portsmouth & VA & 11.8 & 101 \\
\hline Mobile & $\mathrm{AL}$ & 11.8 & 203 \\
\hline Aurora & IL & 12 & 116 \\
\hline Rockford & $\mathrm{IL}$ & 12.5 & 144 \\
\hline
\end{tabular}




\begin{tabular}{lccc} 
City & State & $\begin{array}{c}\text { Homicides } \\
1100 \mathrm{k}\end{array}$ & $\begin{array}{c}\text { Population } \\
\text { in 100k }\end{array}$ \\
\hline LongBeach & CA & 12.6 & 422 \\
Inglewood & CA & 12.6 & 111 \\
South Bend & IN & 12.7 & 102 \\
Kansas & MO & 13.1 & 441 \\
Fort Lauderdale & FL & 13.2 & 152 \\
Oakland & CA & 13.3 & 367 \\
Memphis & TN & 13.4 & 597 \\
Chicago & IL & 13.9 & 2722 \\
Shreveport & LA & 14.1 & 192 \\
Flint & MI & 14.8 & 135 \\
Durham & NC & 16 & 150 \\
Miami & FL & 16.4 & 365 \\
Newark & NJ & 17.1 & 269 \\
Jackson & MS & 19.2 & 193 \\
Detroit & MI & 20.1 & 1000 \\
Atlanta & GA & 20.2 & 402 \\
Birmingham & AL & 20.9 & 259 \\
Las Vegas & NV & 22 & 377 \\
St. Louis & MO & 23.6 & 352 \\
Baltimore & MD & 24.4 & 675 \\
Richmond & VA & 29.3 & 198 \\
Gary & IN & 35.1 & 111 \\
Washington & DC & 36.4 & 543 \\
New Orleans & LA & 42.4 & 477 \\
San Antonio & TX & 55.3 & 107
\end{tabular}

Source:http://www.fbi.gov/ucr/ucrpre97.pdf

\section{REFERENCES}

American College of Surgeons, Committee on Trauma, Early Care of the Injured Patient, 4th ed., Philadelphia, Decker, 1990.

Anderson, R. N., Rosenberg, H.M., Age standardization of death rates : implementation of the year 2000 standard, National Vital Statistics Reports, 1998, 47: n. 3, Available as http://www.cdc.gov/nchs/data/nvsr47_3.pdf.

Chenuil, A., Crespin, L., Pouyaud, L., Patrick, B., Movements of adult fish in a hybrid zone revealed by microsatellite genetic analysis and capture-recapture data, Freshwater Biology, 2000, 43, 1, pp.121-131.

Cockburn, J. S., Patterns of violence in English society: homicide in Kent 1560-1985, Past \& Present, 1991, 130, pp. 70-106.

Cooper, G., Lost Love: A True Story of Passion, Murder, \& Justice, New York, 1869, New York, 1993.

Daly, M., Wilson, M., Homicide, New York, 1988.

Eckberg, D., Stalking the elusive homicide: dual enumeration techniques and postreconstruction South Carolina killings, Paper presented at the Social Science 
History Association annual meeting, Chicago, 1998 and forthcoming Social science history, 2001.

Eisner, M., Modernization, self-control and lethal violence _ long-term dynamics of European homicide rates in theoretical perspective, British Journal of Criminology, forthcoming, 2001.

Emmerichs, M. B., Infanticide and the coroners in nineteenth-century London, European social science history association conference, Amsterdam, April 2000.

Gallman, J. M., Receiving Erin's children : Philadelphia, Liverpool, and the Irish Famine Migration, 1845-1855, Chapel Hill, 2000.

Gurr, T. R., Historical trends in violent crimes: A critical review of the evidence, in Tonry, M., Morris, N., (Eds.), Crime and justice: an annual review of research, 1981, 3, pp. 295-353.

Gurr, T.R., (Ed.), Violence in America, Newbury Park, Calif., 1989.

Hammer, C. I. Jr., Patterns of homicide in a medieval university town: fourteenthcentury Oxford, Past \& present, 1978, 78, pp. 3-23

Lane, R., Violent Death in the City: Suicide, Accident, and Murder in NineteenthCentury Philadelphia, Cambridge, Mass., 1979.

Monkkonen, E., New York City homicide offender ages: how variable? A research note, Homicide Studies, 1999, 3, 3, pp. 256-271.

Monkkonen, E., Murder in New York City, Berkeley and Los Angeles, 2001a.

Monkkonen, E., Estimating the accuracy of historic homicide rates : New York City and Los Angeles, Social Science History, forthcoming $2001 \mathrm{~b}$.

Nadel, S., Infanticide in the New Metropolis, European Social Science History Association Conference, Amsterdam, April 2000.

Sharpe, J. A., Domestic homicide in early modern England, Historical Journal, 1981, 24, 1, pp. 29-48.

Sharpe, J.A., The history of crime in late medieval and early modern England: a review of the field, Social History, 1982, 7, 2, pp. 187-203.

Soman, A., Deviance and criminal justice in western Europe, 1300-1800: an essay in structure, Criminal Justice History, 1980, 1, pp. 1-28.

Spierenburg, P., Long-term trends in homicide: theoretical reflections and Dutch evidence, fifteenth to twentieth centuries, in Johnson, E.A., Monkkonen, E.H., (Eds.), The Civilization of Crime: Violence in Town and Country since the Middle Ages, Urbana, 1996, pp. 63-108.

StataCorp, Stata statistical software: release 6.0, College Station, Texas, 1999.

Stone, L., Interpersonal violence in English society 1300- 1980, Past \& Present, 1983, 101, pp. 22-33.

Sydeman, W. J., Nur, N., McLaren, E. B., McChesney, G. J., Status and trends of the ashy storm-petrel on southeast Farallon island, California, based upon capturerecapture analyses, Condor, 1998, 100,3, pp. 438-447.

Symcox, G., Monkkonen, E.H., The Census of Turin, unpublished article and data set, 1994.

Taylor, H., The politics of the rising crime statistics of England and Wales, 1914-1960, Crime, Histoire \& Sociétés/Crime, History and Societies, 1998a, 2, 1, pp. 5-28.

Taylor, H., Rationing crime : the political economy of criminal statistics since the $1850 \mathrm{~s}$, Economic history review, 1998b, 51, 3, pp. 569-590.

Thome, H., Explaining long term trends in violent crime, Crime, Histoire et Sociétés/Crime, History and Societies, 2001, 5, 2, pp. 69-86. 
Tucher, A., Froth \& Scum: Truth, Beauty, Goodness, and the Ax Murder in America's First Mass Medium, Chapel Hill, 1994.

United States, Center for Health Statistics, US vital statistics system: major activities and developments, 1950-1995, app ii., history and organization of the vital statistics system. http://www.cdc.gov/nchs/data/usvss.pdf.

Wilson, R.F., Walt, A.J., (Eds.), Management of Trauma: Pitfalls and Practice, 2 nd ed., Baltimore, Williams \& Wilkins, 1996.

Ylikangas, H., Five Centuries of Violence in Finland and the Baltic Area, Columbus, 2000 . 